\title{
Corrigendum: Options for managing impacts of climate change on a deep-sea community
}

Ronald E. Thresher, John M. Guinotte, Richard J. Matear and Alistair J. Hobday

Nature Clim. Change 5, 635-639 (2015); published online 24 June 2015; corrected after print 24 June 2015.

In the print version of this Perspective, in the third sentence of the last paragraph of the main text, the quote is incorrectly attributed, and the sentence should have read: As frankly stated to us by a member of an agency concerned with the impacts of climate change on Australia generally, "why should the government or public invest in protecting a community that few people know or care about?". This error has been corrected in the online versions of the Perspective. 